\title{
The Massive Implementation of ICT in Universities and Its Implications for Ensuring SDG 4: Challenges and Difficulties for Professors
}

\author{
Celia Rangel-Pérez ${ }^{1, *}$, María-José Gato-Bermúdez ${ }^{2}$, Daniela Musicco-Nombela ${ }^{3}$ and Cristina Ruiz-Alberdi ${ }^{4}$ \\ 1 Department of Applied Communication Studies, Faculty of Media and Communication Science, \\ Complutense University of Madrid, 28040 Madrid, Spain \\ 2 Postgraduate Pedagogy Department, Faculty of Humanities and Communication, San Pablo CEU University, \\ 28040 Madrid, Spain; mariajose.gatobermudez@ceu.es \\ 3 Department of Communication Studies, Faculty of Communication, Francisco de Vitoria University, \\ 28223 Madrid, Spain; daniela.musicco@ufv.es \\ 4 Department of Education, Faculty of Education and Psicology Francisco de Vitoria University, \\ 28223 Madrid, Spain; c.ruiz.prof@ufv.es \\ * Correspondence: cerangel@ucm.es
}

Citation: Rangel-Pérez, C.; Gato-Bermúdez, M.-J.;

Musicco-Nombela, D.; Ruiz-Alberdi,

C. The Massive Implementation of

ICT in Universities and Its

Implications for Ensuring SDG 4:

Challenges and Difficulties for

Professors. Sustainability 2021, 13,

12871. https://doi.org/10.3390/

su132212871

Academic Editors: Lene Foss,

Liz Browne and Norris Krueger

Received: 10 September 2021

Accepted: 10 November 2021

Published: 21 November 2021

Publisher's Note: MDPI stays neutral with regard to jurisdictional claims in published maps and institutional affiliations.

Copyright: (C) 2021 by the authors. Licensee MDPI, Basel, Switzerland. This article is an open access article distributed under the terms and conditions of the Creative Commons Attribution (CC BY) license (https:/ / creativecommons.org/licenses/by/ $4.0 /)$.

\begin{abstract}
Education has undergone the greatest revolution since the 19th century. The pandemic has massively launched teaching towards the use of ICTs and online education. The main objective of this research is to study the relationship between the adaptation of university faculty to the massive use of ICTs and educational digitization, and the promotion of SDG 4, which establishes Target 4.3, ensuring access to quality university education. To achieve this, a descriptive study methodology is used, in which the results of a validated survey, on a sample of 245 teachers from 32 public and private Spanish universities, were analyzed. The main results consist of the different emotional reactions among professors, finding that, on the one hand, ICTs allow for the development of new skills, the introduction of new methodological proposals, and the development of a positive attitude towards the use of digital tools in order to reach all of their students. However, on the other hand, the results also show that the use of ICTs caused an increase in anxiety, workloads, and the need for ongoing training. There is a need to continue improving the digital competencies of faculty professors in order to favor access to ICTs by university students and, thus, promote quality education worldwide.
\end{abstract}

Keywords: blended learning; Goal 4; SDG; university; digital divide; university professors; ICT

\section{Introduction}

Blended education, massively imposed since September 2020, has had a great impact on the education sector [1], which had, in the previous months, suffered one of the biggest disruptions in history [2]. ICT has been the key to counteracting the closures and overcoming the constraints of the return of lockdown, and it will be used to meet the future challenges of healthcare crises with uncertain end dates [3]. ICT has also made it easier to continue training in different environments [4]. However, in this context, the digital divide generated by the pandemic seriously compromises the targets set in SDG 4, established by The United Nations. Before the pandemic, it was observed that one of the problems was the lack of teacher training as well as educational dropout in countries with social and political conflicts [5]. However, due to the pandemic, it is now being observed that the digital divide also affects countries with greater technological development and better trained teachers [6].

With the advent of the recent pandemic, and the compulsory use of learning, first, at a distance, and then blended in the classroom, university professors have been forced to take a leap in the adoption of ICTs in order to be able to continue guaranteeing the quality of teaching, and meeting Target 4.3 of SDG 4, ensuring access to education [7]. If, on the 
one hand, the worldwide emergency has pushed forward the use of new technologies in university teaching, leading to the development of new skills and methodologies among teachers, on the other hand, it has led university teachers into stressful situations. The quality of teaching itself is at risk because there can be no quality education without emotionally healthy and well-trained teachers, within the framework of the new innovative didactics, in which ICTs should not be a barrier, but a means to achieving quality education, as per SDG 4.

University professors have adopted the use of ICTs, with diverse reactions among the teaching staff, as is evidenced in the survey carried out in this study that focuses on the new practices adopted and the professors' reactions. Professors have been pushed to adopt new methodologies and tools in order to be able to continue guaranteeing continuity in training for their students while trying not to reduce the quality of teaching.

The novelty of this work lies in studying how university professors have been affected by the massive and urgent use of ICTs in the sudden context of synchronous and asynchronous education caused by the COVID-19 health restrictions, and how this may affect their compliance with SDG 4, ensuring access to quality university education.

\subsection{Background}

This change of context has revealed the existence of a digital divide caused by unequal access to technological resources, even in countries with high penetration of new technologies. In this sense, some studies already show the inexorable damage in school dropouts, and in the loss of the ability to maintain studies during confinement in countries with greater social difficulties, due to the lack of technical resources and personnel. For example, according to an investigation carried out in Chile by the Ministry of Education and the World Bank, only $6 \%$ of public educational centers, and $35 \%$ of private centers, could mitigate the damage to students' education caused by holding their classes online during the pandemic [8].

During the confinement, in different countries, there have been numerous initiatives that, through ICTs, have aimed to alleviate the damage of the new scenario that has changed our ways of learning and teaching. The Piazzetta Digitale [9] program was launched in the 2019-2020 school year by the Italian Ministry of Education, during the months of confinement, and because of the isolation measures required by the pandemic, a small virtual meeting space was created. In the United Kingdom, the government issued a statement, in the summer of 2020, inviting different educational institutions to increase outdoor activities and follow models, such as Forest Schools, to reduce risks of contagion [10], an initiative that could also be applied to the university environment.

Since the beginning of the global confinements, breaking social isolation and the challenges of online education have been among the priorities. Another priority has been to curb the growing trend of anguish, anxiety, stress, sadness, apathy, and demotivation among students and professors [11]. Mental illnesses, disorders, and learning difficulties have also been on the increase. Sleep problems, attention deficit, aggressiveness, or depression, have begun to present an inexorable advance [12]. This increase in symptoms has been directly proportional to the increase in the number of cases of teachers with perceived increased workloads and the need for retraining. All of this complicates progress on Goal 4 of the 2030 Agenda. Globally, there have been steps backwards in achieving the Sustainable Development Goal dedicated to "quality education" [13], which aims to provide a new professional perspective, and "it is essential to help teachers develop the mindset and professional skills that will enable them to meet the many challenges they will face throughout their careers" [14].

In Europe, for example, the university dropout rate (understood as young people between 18 and 24 years of age), which, in 2009 , was $14 \%$, had fallen to around $10.2 \%$ in 2019, approaching the European 2020 target, with Spain being the country with the worst percentage, $17.3 \%$. The pandemic and the lockdown have also set back progress in Europe, with the ELET (Early Leavers from Education and Training) index standing at $13.5 \%$ in 
2020, without allowing for the possible worsening of data in 2021 after school closures due to the pandemic [15].

We can see that these problems are manifesting themselves not only in countries with few economic resources, but also in Europe, as with the situation of professors in Spain as presented in this paper. For this reason, the UNESCO reminds us that: "It is essential to protect the physical and mental health of pupils, teachers and educational staff. School closures have led to further disruption of children's and young people's lives and relationships" [16]. In this regard, some professors in the United States are leaving their jobs because they do not feel able to teach digitally [17], so the digital divide is also affecting First World countries [18]. In countries like Spain, high percentages of university professors have suffered from digital imposition. The pandemic, and the consequent technological revolution experienced in the educational field, have increased anxiety among faculty professors over work overload, which translates into stress that can lead to professional burnout syndrome [19]. As previously reported by authors, such as Martinez-Otero [19], teachers who suffer from this syndrome may experience changes at the cognitive level (e.g., difficulty in maintaining attention), and at the emotional level (deep sadness, irritability, etc.) Following the reflection of Fernandez-Abascal, collected by Martinez-Otero [19], if the increase in stress among teachers before the pandemic was already worrying, during the pandemic period, it had increased in its category of unique stressors, which refer to serious alterations in the vital environments of many people. In the postpandemic period (although, unfortunately, it is still too early to determine if the pandemic is actually over), the legacy of the digital revolution in education, with the massive adoption of online education and ICTs, has given way to hybrid educational systems. There are multiple stressors for teachers, in which they face significant modifications in methodologies and the use of new tools that affect them individually, and daily stressors, in which the alteration of routines has been evident in the need to adopt new forms of student-teacher interpersonal communication. The communication is mediated by new technologies that many Spanish universities have chosen to maintain after the lockdown, taking advantage of the shock experienced in order to accelerate the process of educational methodological change in the increase in the presence of ICTs in the classroom. This has led to an inevitable excess of work that, in studies, such as the one carried out in Venezuela with 885 teachers [20], has been identified as one of the most important stressors for teachers.

For different authors, such as Miguel-Tobal [19], anxiety is understood as a variant of fear that refers to indeterminate fear without a concrete danger. The term "anxiety", in relation to stress for professors, refers to the inner experience of restlessness found among faculty professors as one of the main anxiety sources, the technification and the abundance of tasks disconnected from each other, and is also sublimated by stress due to the emotional overload that is produced by a prolonged external force that pushes the subject to the verge of exhaustion. Faced with this emotional suffering, the quality of education decreases [19]. There are also numerous studies that highlight the relationship between work conditions and productivity, and other authors contribute the incidence of anxiety and stress variables in the prediction of teacher depersonalization and low personal fulfillment, which affect the quality of teaching [20].

\section{University, ICT Challenges, and SDG 4}

If universities in countries with more resources are affected by the consequences of the health crisis, with different levels of digitization implemented, it is likely that even more inequalities will be created in universities in developing countries [21], bearing in mind that university education helps to improve employment opportunities for men and women and, therefore, fairer and more egalitarian societies [13].

The digital divide among university students due to the pandemic has been added to the challenges of professors at the university [22,23]. Beyond the advantages of hybrid education, related to efficiency, practicality, and flexibility, its implementation in the university environment remains a challenge [24]. University professors have had to adapt to 
new technologies and methodologies, first, in 100\% remote education, and then during the second and third waves, in blended classes [22], a radical change where technological tools solve the physical distance problem to enable teaching to continue; however, inevitably, the elements that come into play with the use of ICTs also impact on teaching performance and on student learning [25]. The return to classrooms in hybrid teaching with students, some in the classroom and others online, has meant university professors have had to adapt, or change, the contents of the subjects taught to fit this new pedagogical circumstance, and this has forced them to learn how to use cameras and other tools to keep the classes active [26]. Moodle, Zoom, Microsoft Teams, and Google Classroom are some of the most used platforms used to manage teaching content, hold virtual classes, or encourage the interaction of distance classes [27]. There are also other tools, such as WhatsApp, WordPress, Edpuzzle, and H5P, that allow for the interaction between a professor and a student [28,29]. All of them are channels that allow information to be provided, communication between professors and students, as well as self-expression [30].

Digital transformation is affecting many industries, including education, and professors must adapt their materials and assessments to a digital environment in the face of all kinds of technical impediments [31,32]. This implies a change in mentality towards assuming the importance of technology [28], and constant training [26,28], and those professors must dedicate more time and energy to adapt to this digital environment [33], and even to be digitally available to students [34,35], undoubtedly an extra effort, which is closely related to SDG 4, quality education within sustainable development, dedicated to the promotion of lifelong learning opportunities for all [36].

The use of digital resources, such as videos, images, websites, blogs, or online forums, among others, has become the norm in university classes in recent years and has been widely accepted by students $[28,29,31]$. The arrival of the camera increases the need for university faculty professors to be inclusive and to perform at the highest level, even more so if the session is being recorded. In this sense, the professor stops being in the classroom, climbing on a stage [37], becoming somewhat of a showman, and this produces greater exhaustion [38]. This change in model, with the compulsory use of ICT in the classroom, has led to the appearance of new doubts on the parts of professors, directly linked to teacher training [39], evidencing the need for sustainable development linked to lifelong learning. Support for professors with adequate training in the area of digital transformation is necessary in order to reduce the social digital gap in educational technology and achieve informational and digital competence, the so-called CDI [40]. Pedagogical innovation, in this extreme situation caused by the pandemic, could initiate deep reflection and motivate an educational change among professors [41].

The change in the educational scenario that has occurred at the digital level due to COVID-19 responds to a reason with a higher purpose, that is, to save people's lives, which has unexpectedly even subverted the priority order of the 2030 Agenda. It is possible that, in this sense, Goal 4 should also be complemented by the urgent need for equal access to ICTs and the lifelong opportunity for digital literacy for all [42]. ICTs have become tools that are not only useful for teaching innovation and new forms of communication in teaching, but that are also essential allies in guaranteeing the continuity of educational training, a sine qua non across the planet, and the preservation of the progress of civilization and human safeguarding. This can help to make sense of this complicated situation, which means that priority is given to the common good, because this supposes educational reflection on the priority of teaching [43]. A study, carried out in 2019, analyzed how students had integrated the use of ICT into their routines. Professors need to create training spaces with ICT, because it is not of merely instrumental use, but goes much further; the professor must generate training environments where technology is something natural and where the students feel comfortable [44].

As already mentioned, this inequality is also present in more digitized societies. In Spain, it is estimated that $10 \%$ of the 8.2 million Spanish general education students cannot follow classes online. To eradicate this inequality [45], technology has a key role to play in 
helping to meet SDG 4, 4.6, which states that, by 2030, young people, and a large proportion of adults worldwide, will be literate [46]. This goal has been complicated by the COVID-19 pandemic, which has led to absenteeism and learning loss among students, and difficulties for professors. To tackle these problems, the UNESCO has created the Global Coalition for Education COVID-19, with 90 partners from the public and private sectors, for example, the International Telecommunications Union, the Varkey Foundation, the International Labor Organization, and the International Working Team on Teachers for Education 2030 [47].

We must not forget that half of the world is offline and does not have access to a computer or does not have an Internet connection at home. In this sense, despite the fact that many students were able to continue their studies remotely around the world using new technologies, 826 million students were without classes during the pandemic because they did not have access to computers at home. This educational digital divide is much greater in developing countries; for example, in sub-Saharan Africa, 82\% of students lack access to the Internet [48]. In Spain, HAZ has been created, an alliance of collaborations formed by foundations and companies in the field of education. This collaboration aims to find solutions for this new educational challenge [49].

On 25 May 2021, on the occasion of Africa Day, the UNESCO brought together ministers, stakeholders, and private representatives of the education sector in the online Forum of the Global Education Coalition (GEC), entitled "The turn of digital learning in Africa: The Role of Local Eco-systems". Ms. Stefania Giannini, the UNESCO Assistant Director-General for Education, said that the greatest disruption in education in recent history had just been experienced, and that it had exacerbated inequalities and threatened advances in educational development and sustainability. There are also innovations that have the potential to ensure that all children and young people have access to quality education, and that they learn differently and better [50].

Distance education first, and hybrid education later, has hit the most vulnerable populations hardest, especially students with learning difficulties, but also in developed countries, where it has been observed that teachers were not as well trained in ICTs. The UNESCO considers a high level of the indicator, 4.c., as when students receive qualified training from their teachers. In Europe, the Eurostat Agency reports on people's participation in educational activities, financing, and teachers and academic results. Although there are no specific assessments in the region to measure learning, most countries in Europe and North America participate in large-scale international assessments conducted by the IEA and the OECD [7].

\subsection{Research Questions}

The importance of studying how ICTs help to promote the spirit of SDG 4 is key to ensuring access to better university education at the international level. This study aims to demonstrate how Spanish professors, consciously or not, are working on SDG 4, and also to identify the opportunities that can be implemented in higher education. In this sense, the research questions of this paper are: (Q1) What educational possibilities are ICTs facilitating to favor better educational quality? (Q2) How can professors promote greater access to university education? (Q3) What is the relationship between the professors' state of mind and their predisposition to improve the quality of education through the use of ICT? To answer these questions, a descriptive study was carried out on a sample of 245 professors from Spanish universities. Hence, considering that professors were forced to make a qualitative leap in the adoption of ICTs, the novelty of this work lies in analyzing how the use of ICTs has helped to promote SDG 4 to improve access and the quality of university education.

\section{Materials and Methods}

\subsection{Sample}

To study how the use of ICTs has served to promote SDG 4 by improving access to quality university education, a survey among university professors was carried out. The 
sample included the participation of 245 professors from private and public universities in Spain who teach in hybrid format. A total of $50.6 \%$ were men and $49.4 \%$ women. By centers, $42.9 \%$ of the responses came from public centers, and $56.7 \%$ from private centers, detecting $0.4 \%$ of losses in the system. In relation to age, $20 \%$ of the sample of professors were between 25 and 40 years old, $56.7 \%$ were between 40 and 55 years old, and the remaining 23.3\% were over 55 years old. The fieldwork was carried out in March 2021, after the beginning of the second semester in a hybrid format. Therefore, a convenience sample collected through snowball sampling was carried out.

\subsection{Methodology and Instruments}

The research methodology used is a mixed quasi-experimental methodology, combining a literature review on the subject and a snowball convenience sample study. The type of sampling chosen was due to the difficulty encountered in reaching the individuals in the sample by means of probability sampling. The central idea of snowball convenience sampling is that each individual in the study population can nominate other individuals in the population who have the same probability of being selected. Individuals who were chosen were asked to nominate other people, in turn, so that our study group approximated a random sample. To gain scientific validity, the initial individuals were randomly selected before starting.

The instrument selected was a questionnaire that measures attitudes towards ICT by university teachers and that was previously validated among Spanish university teachers [51], so it is considered a relevant instrument for the present research because it allows a psychometric measurement to be made when studying how ICT favors greater access to quality education. The original instrument contained 15 Likert-type questions, to which were added another five questions related to sociodemographic criteria (gender, age, type of center, name of the university, and city in which it is located), as well as a final open question to collect their opinion on their state of mind in the blended classes (How have you felt as a faculty professor during the hybrid classes?) The final questionnaire consisted of a total of 21 questions that teachers answered through electronic means. Regarding the methodology used to analyze the results of the questionnaire, a descriptive study was carried out based on nonparametric statistical Mann-Whitney U and Kruskal-Wallis tests, using the SPSS program (version 27). Regarding the validity and reliability of the study, given that there was a total of 245 observations, it can be stated that the study sample met the requirement of having a minimum of 10 subjects per item [52]. According to the analysis on the internal consistency of the items that make up the measurement instrument, the questionnaire had a Cronbach's alpha value of 0.66 (95\% CI 0.56, 0.74), which is an acceptable value for an exploratory study.

\section{Results}

The analysis of the research is presented below, starting with the analysis of the means and standard deviations of the main items of the study (Table 1).

The highest means that show the greatest agreement in certain statements are for the items: "The use of ICT in teaching implies the development of new skills in students"; "ICT facilitates the research of the university professor"; "The use of ICT in teaching implies that university professors are continuously trained and updated"; and "New methodological possibilities arise in my classes and I can implement new teaching innovations more easily thanks to the incorporation of ICT". The lowest means that indicate disagreement in the statements are found in the items: "The use of technology in my classes improves my students' assessment"; "Thanks to the incorporation of ICT during my classes, students are more motivated in my subject"; and "ICTs promote a higher-level education with a higher degree of interdisciplinarity". 
Table 1. Statistical data with the means and standard deviations with the main items.

\begin{tabular}{|c|c|c|}
\hline Item & Average & Dev. Deviation \\
\hline $\begin{array}{l}\text { The use of ICT in teaching implies the development of new } \\
\text { skills in students. }\end{array}$ & 4.28 & 0.871 \\
\hline More work is done during classes thanks to the use of ICT. & 3.72 & 1.118 \\
\hline $\begin{array}{l}\text { New methodological possibilities arise in my classes and I can } \\
\text { implement new teaching innovations more easily thanks to } \\
\text { the incorporation of ICT. }\end{array}$ & 3.93 & 1.049 \\
\hline $\begin{array}{l}\text { Thanks to the incorporation of ICT during my classes, } \\
\text { students are more motivated in my subject. }\end{array}$ & 3.15 & 1.175 \\
\hline $\begin{array}{l}\text { The use of ICT for the administrative tasks of my subject (class } \\
\text { lists, evaluation, etc.) has meant a significant improvement. }\end{array}$ & 3.70 & 1.264 \\
\hline $\begin{array}{l}\text { ICTs promote a higher level education with a higher degree of } \\
\text { interdisciplinarity. }\end{array}$ & 3.19 & 1.119 \\
\hline $\begin{array}{l}\text { The use of technology in my classes improves my students' } \\
\text { assessment. }\end{array}$ & 3.10 & 1.198 \\
\hline ICTs facilitate the research of the university professor. & 3.97 & 1.201 \\
\hline ICTs improve and facilitate professor-student communication. & 3.72 & 1.241 \\
\hline ICT saves repetitive work. & 3.41 & 1.230 \\
\hline $\begin{array}{l}\text { The use of technology in class makes teaching easier for } \\
\text { university professors. }\end{array}$ & 3.52 & 1.151 \\
\hline $\begin{array}{l}\text { The use of ICT in teaching implies that university professors } \\
\text { are continuously trained and updated. }\end{array}$ & 3.96 & 1.112 \\
\hline Students value my teaching more positively if I use ICT. & 3.47 & 1.136 \\
\hline $\begin{array}{l}\text { University professors have training opportunities to integrate } \\
\text { ICT into their day-to-day classes. }\end{array}$ & 3.78 & 1.043 \\
\hline $\begin{array}{l}\text { The possibilities offered by ICTs make up for the many hours } \\
\text { spent in training. }\end{array}$ & 3.22 & 1.228 \\
\hline
\end{tabular}

Source: authors' own elaboration.

In order to use parametric tests, two assumptions must be met: normality of the distributions, and homoscedasticity, or homogeneity, of the variances. To do this, the Kolmogorov-Smirnov normality test of significance was studied, since the study sample was greater than 50 . The test result was not satisfactory, so nonparametric tests needed to be performed. Specifically, the Mann-Whitney U tests for inhomogeneous distributions, and Kruskal-Wallis tests were used to observe the significant differences in the questionnaire items.

As it is a nonhomogeneous distribution, the Mann-Whitney $U$ test was carried out with the sociodemographic criteria: sex, age, type of center, name of the university, and city where the university is located. In the results with the gender criterion, in the item "The use of ICT in teaching implies that university professors are continuously trained and updated" $(\mathrm{Z}=-2.063 ; p<0.001$; Wilcoxon's $\mathrm{W}=14,167.000)$, significant differences were found with the sex of the survey participants (Table 2). The average range for the independent variable man being 114.25, and for the woman being 131.97, it could be concluded that women think, with greater intensity than men, that the use of ICT implies constant training and updating. On the other hand, after performing the Mann-Whitney $U$ test for all items and observing whether there were significant differences with the rest of the aforementioned sociodemographic criteria, it was determined that there were no significant differences. 
Table 2. Descriptive statistics of the item "The use of ICT in teaching implies that university professors are continuously trained and updated".

\begin{tabular}{lccccc}
\hline \multicolumn{1}{c}{ Item } & No. & Average & Dev. Deviation & Minimum & Maximum \\
\hline $\begin{array}{l}\text { The use of ICT in } \\
\text { teaching implies that } \\
\text { university professors are }\end{array}$ & 245 & 3.96 & 1.112 & 1 & 5 \\
$\begin{array}{l}\text { continuously trained } \\
\text { and updated }\end{array}$ & 245 & 0.49 & 0.501 & 0 & 1 \\
\hline Sex & & & &
\end{tabular}

To observe the significant differences of the survey items according to age ranges, the Kruskal-Wallis test was performed for independent samples, to preserve or reject the null hypothesis (there were no significant differences between the items and the age variable), where it was concluded that there were significant differences in two items: "More work is carried out during classes thanks to the use of ICT" and "The use of ICT in teaching implies that university professors are continuously trained and updated". The results of the analysis of these two items are detailed below(Tables 3 and 4).

Table 3. Summary of the Kruskal-Wallis test for the item "More work is done during classes thanks to the use of ICT" and age.

\begin{tabular}{lc}
\hline Total No. & 245 \\
\hline Test statistic (adjusted for ties) & 13.274 \\
Degree of freedom & 2 \\
Asymptotic sig. (two-tailed test) & 0.001 \\
\hline
\end{tabular}

Source: authors' own elaboration.

Table 4. Summary of the Kruskal-Wallis test for the item "The use of ICT in teaching implies that university professors are continuously trained and updated" and age.

\begin{tabular}{lc}
\hline Total No. & 245 \\
\hline Test statistic (adjusted for ties) & 6.887 \\
Degree of freedom & 2 \\
Asymptotic sig. (two-tailed test) & 0.001 \\
\hline Source: authors' own elaboration. &
\end{tabular}

There were significant differences between the item "More work is carried out during classes thanks to the use of ICT" and age. In the 25-40 age group, they did not consider that more work was carried out, while those 40 and over did think that ICT allowed them to develop more work during classes.

There were significant differences between the item "The use of ICT in teaching implies that university professors are continuously trained and updated" and age, given that the group between 40 and 55 years old believe that the use of ICT does imply a constant updating, while the two other groups (between 25 and 40 years old, and more than 55 years old) do not consider that such updating and training is required.

Faced with the open question of how the university teaching staff have felt during the synchronous and asynchronous classes, after performing the Kruskal-Wallis test, it was found that there were no significant differences by age range in this question.

When analyzing the responses (Table 5), on the one hand, messages of security, improvement, and adaptation to the situation stand out; however, on the other hand, feelings of fatigue, distance, frustration, exhaustion, resignation, or fear are repeated. Other responses highlight a greater workload and the difficulty of connecting with students in virtual group classes, although this connection was achieved during individual online tutorials. 
Table 5. Descriptive statistics of the item "How have you felt as a faculty professor during the hybrid classes?"

\begin{tabular}{lcc}
\hline & Frequency & Percent (\%) \\
\hline Feeling of self-challenge & 3 & 1.2 \\
Concern & 13 & 5.3 \\
Comfort & 27 & 11.0 \\
Overwork anxiety & 6 & 2.4 \\
Emotional ups and downs & 10 & 4.1 \\
Intense stress & 4 & 1.6 \\
Satisfaction & 5 & 2.0 \\
Feelings of being paid by the institutions & 2 & 0.8 \\
Extreme fatigue & 1 & 0.4 \\
Feeling of adaptive challenge & 10 & 4.1 \\
Anxiety & 6 & 2.4 \\
Sadness & 4 & 1.6 \\
Helplessness & 6 & 2.4 \\
Isolation/loneliness & 26 & 10.6 \\
Intense mental exhaustion & 8 & 3.3 \\
Fear/uncertainty & 4 & 1.6 \\
Motivation & 5 & 2.0 \\
Well & 70 & 28.6 \\
Lost & 3 & 1.2 \\
Multitasking professor & 3 & 1.2 \\
Frustration & 8 & 3.3 \\
Opportunity to grow & 1 & 0.4 \\
Limitation in teaching & 6 & 2.4 \\
Difficulty in assessing and following up with students & 4 & 1.6 \\
Alienated & 4 & 1.6 \\
Undervalued & 2 & 0.8 \\
\hline Source: & 3 &
\end{tabular}

Source: authors' own elaboration.

The main results of the analysis are summarized below:

- Spanish university professors agree that the use of ICT helps to develop new skills in students, helps to introduce new methodologies, facilitates their research work, and implies their constant updating as professionals.

- Regarding updating and recycling, there are differences by age and by sex. Women believe that the use of ICT implies training and regular updating. By age, the group of professors between 40 and 55 years old coincide with this same statement.

- Professors aged 40 and over consider that more work is done during classes thanks to the use of ICT.

- University professors agree that the use of ICT does not imply that students get better grades, or that they are more motivated, or that there is more interdisciplinarity in education.

- Finally, in general, university professors' feelings of frustration and exhaustion when faced with hybrid classes outweigh positive feelings related to resilience.

\section{Discussion}

The results of the research highlight, on the one hand, the use of technology as a means to reach students in situations of restrictions, such as the one caused by COVID-19, as well as the giant leap that has been made in the adoption of ICTs by university professors. However, if we take this beyond the obvious, we see the enormous possibilities that technology has to reach millions of people, in different parts of the planet, so that they can have a quality university education, regardless of place or time. This undoubtedly marks a before and an after in the scope of the university and in its contribution to SDG 4 of the 2030 Agenda. These new educational environments require new educational methodologies that begin, for example, by transforming the conception of the educational center itself, since the physical is no longer the center of knowledge. 
Thanks to ICTs, educational networks can be created that connect different parts of the world and favor connections between people. We are social beings who need the company, physical or virtual, of our peers, and, in these new educational environments, the role of the teacher is essential. Beyond teaching their classes synchronously or asynchronously, this is a fundamental axis to promoting the ethical values that unite us as people through accompaniment, empowerment, and empathy. Therefore, university professors also require constant training, beyond the technical in digital tools, but within a humanistic and ethical perspective that puts focus on the values that we must reinforce in our society, considering that more people will have more access to a quality university education around the world, thanks to ICT.

A final implication of the work being done at universities to favor SDG 4 is that it can be diverted for the direct improvement of other goals, such as SDG 1 (ending poverty), SDG 2 (reducing the number of hungry people), SDG 3 (health and well-being), SDG 5 (gender equality), SDG 8 (decent work and economic growth), SDG 10 (reducing inequalities), SDG 16 (fostering peace, justice, and strong institutions), and SDG 17 (partnerships to achieve the SDGs). Education is the basis for creating a better world, where ICTs are a great ally.

\section{Conclusions}

The great disruption experienced worldwide in the education sector since 2020 due to COVID-19 [2] has accelerated what had been a trend in the use of digital resources in university classes $[28,29,31]$. This digitization had to be accelerated to respond to the health crisis [38] and to enable the continuation of teaching in different environments produced by different health scenarios. The digital transformation accelerated by COVID-19 has meant that university professors have had to adapt and train, in record time, in the use of new platforms and digital tools in order to continue with educational activity $[3,27,29,31]$, causing situations of stress and exhaustion among professors [33]. This heterogeneous situation, in terms of emotional management in the face of the use of ICTs, has slowed down the progress of educational quality required by Goal 4 of sustainable development, part of the 2030 Agenda and the SDGs, but it has also created new opportunities.

Regarding (Q1), the educational possibilities that ICTs are facilitating to favor a better educational quality, we can observe that Spanish professors have focused on the advantages offered by these tools in a blended learning context, among which stand out the promotion of new skills in students, the introduction of innovations in teaching, an improvement in their research work, and constant updating as professionals. Beyond the lack of certainties that we are experiencing [41], Spanish professors have shown great positivity and adaptation when facing the hybrid contexts of education at university, although they have also experienced situations of fatigue due to heavier workloads. This situation encourages us to reflect on what must be taught at the university, what is the priority, and what methods should be followed to make sure that ICTs promote access to a quality university education. All these questions require new training, but to guarantee the quality education sought in Goal 4 of sustainable development, a deep reflection on the ultimate educational meaning is also needed.

Concerning (Q2), how professors can promote greater access to university education, we can highlight that there are differences in the main sociodemographic variables in the approach to ICT in terms of training requirements and the updating of its use, regardless of the center of origin of the people who participated in the study. Sustainable Development Goal 4, quality education for learners, cannot be achieved without promoting lifelong learning opportunities for all professors. In this sense, in a country such as Spain, with a good level of education, qualified professors are having difficulties with digital competence, especially those over 55 years of age. It would, therefore, be in the group of 55 and above, as well as those under 40 , where it is necessary to influence greater training efforts to guarantee the point of Goal 4, making the equal promotion of training opportunities permanent for all, in order to guarantee the educational quality required in sustainable development. Apart from that, regarding the work carried out in the classroom, university 
professors over 40 years of age do consider that ICTs allow more activities to be carried out. Women professors are most aware of the constant updating and training required by ICT to be up-to-date with all the new tools and functionalities within the context of hybrid teaching. By age group, it can be concluded that professors between 40 and 55 years old are very involved in their technological recycling to make the most of hybrid teaching.

Given (Q3), how professors can promote greater access to university education, we can conclude that COVID-19 has not diminished the enthusiasm of a large proportion of Spanish professors to innovate, to seek new sources, and new resources, or to initiate new methodologies. The change in the educational scenario that has occurred at university due to COVID-19 responds to a reason with a higher purpose that should be remembered because it is the veil that surrounds the entire pandemic and consists of saving people's lives. This can help to make sense of this complicated situation and to keep professors' spirits up, which means that priority has been given to the common good, a principle of social ethics that reminds us of the dignity of the person, and that must be valued when talking about pedagogical innovation and the recognition of all the positives that a new point of view can bring to us. Education is an activity that can be seen in the long term, since the effort involved in trying to do things well for "the other" will eventually bear fruit, especially if professors are capable of not missing this train as a transformation opportunity.

Blended teaching using ICT, with half of the students in the classroom and the other half on the other side of the screen, increases the efforts of professors, and increases the difficulties for the student trying to concentrate and, at the same time, avoid technological failures. However, these new difficulties also open opportunities for growth in the development of skills and qualities, with updated abilities in soft skills, such as understanding and generosity. The new complex situations of the synchronous and asynchronous classroom contexts have led to greater exhaustion, both for students and professors. The exercise of a greater tolerance to the frustration that the pandemic has brought, and mixed education in university classrooms, face-to-face and online, could lead, as a response, to growth in the patience, tenacity, responsibility, and strength of the university educational group. In the new hybrid context, the discipline of adapting to, and accepting, the organization of a difficult situation is exercised, and this could be the basis for achieving a greater maturity among students, as well as a greater understanding on the part of professors. This represents a strength for professors because of the great flexibility that they have generated by living all kinds of teaching modalities, imposed by the discipline of the health regulations [22].

To promote better access to a quality university education, "no prioritization would make sense if it does not seek to reach everyone. The digital gap marked by Internet access reveals that not all students have the same opportunities" [44] (p. 56), and this puts at risk the sense of equality implicit in sustainable development, and its Goal 4 . It is probable that the pandemic has favored the revision of ethical and moral values [53], especially in Western societies. The globalized information that has become generalized during COVID-19 has allowed a certain union to be generated between all countries and, perhaps, is positive, as it assumes the concept of human brotherhood. This idea cannot be alien to professors in the face of this new educational paradigm. The vision that a crisis provides us is a good opportunity to reflect on what type of professor you want to be. The road has begun so that each professor can analyze, and continue to recover, all of the ethical and moral values reinforced by the difficulties caused by the pandemic, without forgetting that hope and improvement illuminate this new educational scenario. It is assumed that there can be no quality education without emotionally healthy and well-trained professors within the framework of the new innovative didactics, in which ICTs should not be a barrier, but a means to achieving quality education, as per SDG 4 [54].

To overcome the limitations of this study, it would be appropriate to compare how access to quality education through ICTs is being promoted with another of the groups that have had to teach synchronous and asynchronous classes in Spain, such as 3rd and 4th ESO teachers. It would also be interesting to compare the feelings of professors and 
teachers in order to analyze whether the educational stages of the students influence how this hybrid teaching situation is faced on an emotional level. For future work, it is also necessary to analyze which ICTs are still being used after the massive and forced digital transformation in the educational field, and to verify the application of new teaching innovation practices by age and gender. Moreover, it would also be very useful to know how the new digital divides that concern professors, and those that refer to students, are manifesting in other developed countries, and to make comparisons and verify useful practices appliable to countries in the process of development, because only by overcoming these gaps globally can quality education be guaranteed for sustainable social development worldwide. Moreover, to monitor the role of university education for society, politicians, and the various stakeholders involved in the education sector, it will be necessary to monitor the evolution of the number of students worldwide and compare it with the GDP of each country in order to show how greater access to quality university education contributes to economic growth.

Author Contributions: Conceptualization, C.R.-P., M.-J.G.-B., D.M.-N. and C.R.-A.; methodology and formal analysis, M.-J.G.-B.; investigation, C.R.-P., M.J-.G., D.M.-N. and C.R.-A.; writing-original draft preparation, C.R.-P., M.-J.G.-B., D.M.-N. and C.R.-A.; writing-review and editing, C.R.-P., D.M.-N. and C.R.-A. All authors have read and agreed to the published version of the manuscript.

Funding: This research received no external funding.

Institutional Review Board Statement: Not applicable.

Informed Consent Statement: Not applicable.

Data Availability Statement: All data are available to the academic community. Please contact Celia Rangel (cerangel@ucm.es).

Conflicts of Interest: The authors declare no conflict of interest.

\section{References}

1. He, W.; Zhang, Z.; Li, W. Information technology solutions, challenges, and suggestions for tackling the COVID-19 pandemic. Int. J. Inf. Manag. 2021, 57, 102287. [CrossRef] [PubMed]

2. Pokhrel, S.; Chhetri, R. A literature review on impact of covid-19 pandemic on teaching and learning. High. Educ. Future 2021, 8 , 133-141. [CrossRef]

3. Mawere, T.; Sambo, P. Technology and Its Impacts in Higher Education Post COVID-19. Social Science Research Network. 2021. Available online: https:/ / papers.ssrn.com/abstract=3817344 (accessed on 2 September 2021).

4. OECD. Education Responses to COVID-19: Embracing Digital Learning and Online Collaboration. 2020. Available online: https: / / cutt.ly/Wnyn7TG (accessed on 6 September 2021).

5. UNDP. Goal 4, Quality Education. Available online: https://cutt.ly/bWSo6Dz (accessed on 9 September 2021).

6. Ramos-Huenteo, V.; García-Vásquez, H.; Olea-González, C.; Lobos-Peña, K.; Sáez-Delgado, F. Percepción docente respecto al trabajo pedagógico durante la COVID-19. CienciAmérica 2020, 9, 334-353. [CrossRef]

7. UNESCO. Guía Abreviada de Indicadores de Educación para el ODS 4. 2018. Available online: https://cutt.ly/5Rqkp0u (accessed on 1 September 2021).

8. Fischman, P.; Irarrazaval, M. Debate: Mental health, social crisis and the COVID-19 pandemic in Chile. Child Adolesc. Ment. Health 2020, 25, 256-257. [CrossRef]

9. Mattana, D. La Piazzetta Digitale, Ascolto e Confronto a Portata di Click. Interris. 5 June 2020. Available online: https: / / bit.ly /3hYIiwm (accessed on 4 September 2021).

10. Ibáñez, F. Escuelas Bosque: Una Solución para las Instituciones Educativas Pospandemia; Observatorio de Innovación Educativa, Tecnológico de Monterrey: Mexico DF, Mexico, 9 November 2020. Available online: https://cutt.ly/iQNpJvx (accessed on 2 September 2021).

11. Golberstein, E.; Wen, H.; Miller, B.F. Coronavirus Disease 2019 (COVID-19) and Mental Health for Children and Adolescents. JAMA Pediatrics 2020, 174, 819-820. [CrossRef]

12. Nobili, L. Impatto Psicologico e Comportamentale sui Bambini delle Famiglie in Italia. Informe del Irccs Hospital Gaslini \& Universitá degli Studi di Genova. 2020. Available online: https:/ / bit.ly/3wLmV69 (accessed on 6 September 2021).

13. Kioupi, V.; Voulvoulis, N. Education for sustainable development: A systemic framework for connecting the SDGs to educational outcomes. Sustainability 2019, 11, 6104. [CrossRef]

14. Reimers, F. Educación Global para Mejorar el Mundo; Biblioteca Innovación Educativa: Madrid, Spain, 2020. 
15. Eurostat. Early Leavers from Education and Training. 2021. Available online: https://cutt.ly/xQNaAn1 (accessed on 1 September 2021).

16. UNESCO. One Year into COVID-19 Education Disruption: Where do We Stand? 2021. Available online: https://cutt.ly/ dQNaHmv (accessed on 2 September 2021).

17. Akella, D.; Rolla, K.P.; Sharma, L.S. Reflections of Faculty Teaching Online During the COVID-19 Pandemic. In Handbook of Research on Inequities in Online Education During Global Crises; Kyei-Blankson, L., Blankson, J., Ntuli, E., Eds.; IGI Global: Hershey, PA, USA, 2021; pp. 43-76. Available online: https: / cutt.ly/zRqkBnx (accessed on 2 September 2021).

18. Iberdrola. Digital Divide Throughout the World and Why It Causes Inequality. 2021. Available online: https://cutt.ly/NQNsqlQ (accessed on 9 September 2021).

19. Martínez-Otero, V. Estrés y ansiedad en los docentes. PULSO. Rev. Educ. 2003, 26, 9-21.

20. Granados, L.; Aparisi, D.; Inglés, C.J.; Aparicio-López, M.D.P.; Fernández-Sogorb, A.; García-Fernández, J.M. ¿Predicen los factores de depresión, ansiedad y estrés la dimensión de la despersonalización y la baja realización personal en el profesorado? Eur. J. Child Dev. Educ. Psychopathol. 2019, 7, 83. [CrossRef]

21. Altbach, P.G.; Wit, H. Post-pandemic outlook for higher education is bleakest for the poorest. Int. High. Educ. 2020, 102, 3-6.

22. Esteban-Navarro, M.A.; García Madurga, M.A.; Morte-Nadal, T.; Nogales-Bocio, A.I. The Rural Digital divide in the Face of the Covid-19. Pandemic in Europe-Recommendations from a Scoping Review. Informatics 2020, 7, 54. [CrossRef]

23. Bruggeman, B.; Tondeur, J.; Struyven, K.; Pynoo, B.; Garone, A.; Vanslambrouck, S. Experts speaking: Crucial teacher attributes for implementing blended learning in higher education. Internet High. Educ. 2021, 48, 100772. [CrossRef]

24. Mendoza-Castillo, L. Lo que la pandemia nos enseñó sobre la educación a distancia. Rev. Latinoam. Estud. Educ. 2020, 50, 343-352. [CrossRef]

25. Serra, M.S. Continuidad pedagógica en pantalla: Entre la disputa de lenguajes y las posibilidades creativas. In Pensar la Educación en Tiempos de Pandemia: Entre la Emergencia, el Compromiso y la Espera; Dussel, I., Ferrante, P., Pulfer, D.D., Eds.; Unipe Editorial Universitaria: Buenos Aires, Argentina, 2020; pp. 315-323. Available online: https:/ / cutt.ly/1QNs7M2 (accessed on 8 September 2021).

26. Milićević, V.; Denić, N.; Milićević, Z.; Arsić, L.; Spasić-Stojković, M.; Petković, D.; Stojanović, J.; Krkic, M.; Milovančević, N.S.; Jovanović, A. E-learning perspectives in higher education institutions. Technol. Forecast. Soc. Chang. 2021, 166, 120618. [CrossRef]

27. Álvarez-Álvarez, C. Video Technologies for Professor-Student Interaction in Online Teaching. In Proceedings of the 3rd International Conference on Teaching, Learning and Education, Amsterdam, The Netherlands, 26-28 February 2021. Available online: https: / / cutt.ly / 9nynLjN (accessed on 2 September 2021).

28. Ntshwarang, P.N.; Malinga, T.; Losike-Sedimo, N. Elearning tools at the university of Botswana: Relevance and use under covid-19 crisis. High. Educ. Future 2021, 8, 142-154. [CrossRef]

29. Vilarinho-Pereira, D.R.; Fleith, D.S. Creative use of information and communication technologies according to university professors and students. Estud. Psicol. 2021, 38, e190164. [CrossRef]

30. Camilleri, M.A. Shifting from traditional and blended learning approaches to a fully virtual and remote course delivery: Implications from COVID-19. Acad. Lett. 2021, 481. [CrossRef]

31. Weisberger, M.; Grinshtain, Y.; Blau, I. How do technological changes in formal education shape the social roles of teachers who are mothers? Teach. Teach. Educ. 2021, 103, 103344. [CrossRef]

32. Shamir-Inbal, T.; Blau, I. Micro-learning in designing professional development for ICT teacher leaders: The role of self-regulation and perceived learning. Prof. Dev. Educ. 2020, 1-17. [CrossRef]

33. Kale, U.; Goh, D. Teaching style, ICT experience and teachers' attitudes toward teaching with Web 2.0. Educ. Inf. Technol. 2014, 19, 41-60. [CrossRef]

34. Bouhnik, D.; Deshen, M. WhatsApp goes to school: Mobile instant messaging between teachers and students. J. Inf. Technol. Educ. Res. 2014, 13, 217-231. [CrossRef]

35. UNESCO. Sustainable Development Goal 4 (SDG 4). 2016. Available online: https:/ / cutt.ly/4QNds6D (accessed on 5 September 2021).

36. Lufkin, B. Why Zoom Fatigue Won't Last Forever. BBC. 8 March 2020. Available online: https:/ /bbc.in/3i3SQdI (accessed on 2 September 2021).

37. Jiang, M. The Reason Zoom Calls Drain Your Energy. BBC. 22 April 2020. Available online: https://bbc.in/34xC7HD (accessed on 3 September 2021).

38. Miralles-Martínez, P.; Gómez-Carrasco, C.J.; Arias-González, V.; Fontal-Merillas, O. Digital resources and didactic methodology in the initial training of History teachers. Comunicar 2019, 27, 45-56. [CrossRef]

39. Sales, D.; Cuevas-Cerveró, A.; Gómez-Hernaández, J.A. Perspectives on the information and digital competence of Social Sciences students and faculty before and during lockdown due to Covid-19. Prof. Inf. 2020, 28, e290423. [CrossRef]

40. Moreno-Correa, S.M. La innovación educativa en los tiempos del Coronavirus. Salut. Sci. Spiritus 2020, 6, 14-26.

41. Official Journal of the European Unions. Council Conclusions on Digital Education in Europe's Knowledge Societies. 2020. Available online: https:/ / cutt.ly/gWSuQ8F (accessed on 9 September 2021).

42. Serrano-Prato, G.P. Liderazgo educativo en tiempos post pandemia. Aportes clave desde una mirada filosófica educativa. Pontificia Universidad Católica de Ecuador. Rev. Saberes 2020, 3, 48-68. 
43. Colás, P.; Conde, J.; Reyes de Cózar, S. El desarrollo de la competencia digital desde un enfoque socio cultural. Comunicar 2019, 61, 21-32. [CrossRef]

44. UNICEF. La Brecha Digital Impacta en la Educación. 2020. Available online: https:/ / cutt.ly/kWSscjk (accessed on 2 September 2021).

45. Mobile World Capital. La Brecha Digital, el Mayor Obstáculo para la Educación Online. 23 April 2021. Available online: https: / / cutt.ly / kWSWSZO (accessed on 4 September 2021).

46. Ministerio de Derechos Sociales y Agenda 2030. Objetivo 4. Educación de Calidad. Available online: https://cutt.ly/uWSEw5s (accessed on 5 September 2021).

47. UNESCO. Global Education Coalition Explores the Digital Learning Turn in Africa. 26 May 2021. Available online: https: / / cutt.ly / dWSQ40V (accessed on 1 September 2021).

48. UNESCO. Startling Digital Divides in Distance Learning Emerge. 21 April 2020. Available online: https://cutt.ly / RWSodVR (accessed on 3 September 2021).

49. HAZ. Alianza por la Educación-Unidos para Transformar la Sociedad a Través de la Educación. Available online: https: / / hazeducacion.es / (accessed on 6 September 2021).

50. Huth, J.; DeLorme, D.E.; Reid, L.N. Perceived third-person effects and consumer attitudes on preventing and banning DTC advertising. J. Consum. Aff. 2006, 40, 90-116.

51. Hernández-Ramos, J.P.; Martínez-Abad, F.; García Peñalvo, F.J.; Herrera García, M.E.; Rodríguez-Conde, M.J. Teachers' attitude regarding the use of ICT. A factor reliability and validity study. Comput. Hum. Behav. 2014, 31, 509-516. [CrossRef]

52. Nunnally, J.C.; Bernstein, I.H. Psychometric Theory; McGraw-Hill: New York, NY, USA, 1994.

53. Guardia, S.B. Educación y Pandemia. El reto de una Formación Humanística y ética. Cátedra UNESCO Patrimonio Cultural y Turismo Sostenible. 2020. Available online: https:/ / bit.ly/3yK3Rqw (accessed on 2 September 2021).

54. Becerra, A.E. Innovación Educativa en Época de Pandemia; Centro de Innovación Educativa Universidad Panamericana: Mexico DF, Mexico, 2021. Available online: https:/ / bit.ly/2R1ELCA (accessed on 8 September 2021). 